\title{
Evaluation of the EU Policy Concerning the Basic Economic Functions of a Modern Government in a Mixed Economy
}

\author{
Pavel Rousek ${ }^{1 *}$ \\ ${ }^{1}$ Institute of Technology and Business, School of Expertness and Valuation, Okružní 517/10, 37001 \\ České Budějovice, Czechia
}

\begin{abstract}
The paper analyses the budget of the European Union in terms of its redistribution power and stabilization efficiency. The redistribution of finance from rich regions to poorer ones is an important function of public budgets. The EU budget only partially fulfils this function. Stabilizing economic development is another important function of public budgets. Also, the effectiveness of the EU budget in this area is not sufficient and could be significantly strengthened.

Key words: macro-economy, policy, government, mixed economy
\end{abstract}

\section{Introduction}

There are some basic economic functions of a government in a modern mixed economy. The evaluation of the correspondence of theory with the practice of the European Union is the subject of this paper.

\subsection{Macroeconomic Government Functions}

Samuelson and Nordhaus [1] define the modern mixed economy as "a combination of private enterprise working through the marketplace and government regulation, taxation, and programs." The importance of the public sector for the modern economy is also underlined by another Nobel Prize winner [2]. This shows that the importance of the public sector and large national economies are considerable. This applies to all the major economies of the globalized world, such as the United States, the European Union or China.

There are three basic macroeconomic functions of any government in a modern mixed economy [3]:

- Allocation function to achieve efficiency,

- Redistribution function to achieve equity,

- Stabilization function to achieve stability.

\footnotetext{
*Corresponding author: rousek@mail.vstecb.cz
} 


\subsubsection{Allocation Function}

The allocation function means the amount and structure of funds directed to the production of public and private goods and services. Generally, it means public goods and services providing: national defence, government administration etc. These goods and services cannot be provided through the market mechanism. However, these goods are essential for consumers [4].

Broadway and Keen [5] deal with allocation efficiency and optimal direction of transfers. However, this is rather a microeconomic topic. From a macroeconomic perspective, redistribution and stabilization are more important.

\subsubsection{Redistribution Function}

The redistribution function means the degree of redistribution of public funds to reduce inequalities in the distribution of income and property. The tools to achieve these goals are taxes and subsidies.

Redistribution through public budgets is an important function of modern government. The influence of political rivalry on redistribution in society is investigated, for example, by [6]. In their article, they abstract from the influence of the voter-median and focus more on the rivalry of the two political parties. Other aspects of redistribution are dealt with by Wildasin, namely the results of redistribution in the labour market [7] or the interaction of redistribution and migration [8].

\subsubsection{Stabilization Function}

The stabilization function means the possibility of public finances to influence the main macroeconomic indicators such as stable economic growth, unemployment, inflation rate, external trade balance, etc.

The importance of stabilizing macroeconomic variables through public budgets shows the interest of experts in this area. The impact of fiscal rules on the stabilizing function of fiscal policy is examined by [9]. Their research is based on data from 21 OECD countries in almost thirty years. One of their most important findings is that „fiscal rules are unable to affect the inflation-destabilising nature of discretionary policy, if any, probably because of the higher importance of central banks in that respect" [9].

\section{European Union Policies}

\subsection{EU Policy of Redistribution}

Following a policy of effective redistribution means allocating budget resources to the EU Member States with the low gross domestic product per capita. This allocation of funds enables the reduction of inequality in the product (or income) in various locations of the European Union. 
Table 1. GDP per Capita in EU Member States (EUR per Capita in 2017).

\begin{tabular}{|l|r|}
\hline \multicolumn{1}{|c|}{ Country } & \multicolumn{1}{c|}{ GDP } \\
\hline Austria & $43,130.57$ \\
\hline Belgium & $38,833.46$ \\
\hline Bulgaria & $7,173.23$ \\
\hline Croatia & $11,594.40$ \\
\hline Cyprus & $23,106.04$ \\
\hline Czechia & $18,185.42$ \\
\hline Denmark & $51,059.28$ \\
\hline Estonia & $17,981.82$ \\
\hline Finland & $40,908.83$ \\
\hline France & $34,505.75$ \\
\hline Germany & $40,362.55$ \\
\hline Greece & $16,369.01$ \\
\hline Hungary & $12,586.79$ \\
\hline Ireland & $63,537.10$ \\
\hline Italy & $28,373.02$ \\
\hline Latvia & $13,611.12$ \\
\hline Lithuania & $14,442.73$ \\
\hline Luxembourg & $98,369.68$ \\
\hline Malta & $25,946.56$ \\
\hline Netherlands & $43,610.43$ \\
\hline Poland & $12,292.05$ \\
\hline Portugal & $18,758.30$ \\
\hline Romania & $9,458.17$ \\
\hline Slovakia & $15,651.27$ \\
\hline Slovenia & $20,844.71$ \\
\hline Spain & $25,109.36$ \\
\hline Sweden & $48,754.87$ \\
\hline United Kingdom & $35,947.30$ \\
\hline European Union & $\mathbf{3 0 , 1 9 0 . 8 6}$ \\
\hline &
\end{tabular}

Source: Author; Data: [10].

A high level of redistribution means a strong negative correlation between GDP per capita and EU budget expenditure. This would mean that the highest spending goes to countries with the lowest per capita GDP. 
Table 2. Structure of the EU Budget per Capita by EU Member States (EUR per Capita in 2017).

\begin{tabular}{|c|c|c|c|c|c|c|c|}
\hline Country & Total & Agriculture & $\begin{array}{c}\text { Regional } \\
\text { policy }\end{array}$ & $R \& D^{1}$ & Citizenship $^{2}$ & $\begin{array}{l}\text { Outside } \\
\text { the } \mathrm{EU}^{3} \\
\end{array}$ & $\operatorname{Admin}^{4}$ \\
\hline Austria & 203.23 & 140.70 & 9.91 & 42.16 & 7.51 & 0.00 & 2.94 \\
\hline Belgium & 653.54 & 46.86 & 27.23 & 128.28 & 22.72 & 0.00 & 428.45 \\
\hline Bulgaria & 263.21 & 140.89 & 87.11 & 25.90 & 7.76 & 0.01 & 1.54 \\
\hline Croatia & 156.94 & 74.11 & 64.47 & 10.25 & 2.76 & 3.23 & 2.12 \\
\hline Cyprus & 243.98 & 87.72 & 75.25 & 56.52 & 9.69 & 0.00 & 7.04 \\
\hline Czechia & 369.58 & 107.03 & 245.08 & 14.46 & 1.50 & 0.00 & 1.51 \\
\hline Denmark & 257.76 & 183.05 & 13.71 & 47.77 & 2.77 & 0.00 & 10.45 \\
\hline Estonia & 493.26 & 179.11 & 214.94 & 45.92 & 46.75 & 0.00 & 6.54 \\
\hline Finland & 274.25 & 159.58 & 47.07 & 55.44 & 5.63 & 0.00 & 6.52 \\
\hline France & 203.34 & 137.79 & 18.48 & 39.04 & 2.58 & 0.00 & 5.41 \\
\hline Germany & 134.57 & 74.75 & 25.39 & 29.24 & 2.00 & 0.00 & 2.81 \\
\hline Greece & 472.47 & 262.47 & 143.21 & 29.31 & 34.90 & 0.00 & 2.56 \\
\hline Hungary & 410.85 & 153.91 & 217.19 & 34.48 & 3.65 & 0.00 & 1.62 \\
\hline Ireland & 392.81 & 325.85 & 10.99 & 39.19 & 5.61 & 0.00 & 11.18 \\
\hline Italy & & 81.15 & 26.84 & 24.08 & 5.29 & 0.00 & \begin{tabular}{|l|}
4.57 \\
\end{tabular} \\
\hline Latvia & 370.93 & 198.53 & 147.19 & 13.75 & 7.28 & 0.00 & 4.18 \\
\hline Lithuania & & 244.78 & 234.64 & 45.41 & 10.59 & 0.00 & 3.63 \\
\hline Luxembourg & $3,245.55$ & 67.50 & 84.43 & 408.01 & 60.50 & 0.00 & $2,625.12$ \\
\hline Malta & 468.88 & 32.26 & 239.25 & 30.56 & 151.18 & 0.00 & 15.63 \\
\hline Netherlands & 143.02 & 53.34 & 11.36 & 55.71 & 15.76 & 0.00 & 6.86 \\
\hline Poland & 313.67 & 107.29 & 197.72 & 5.66 & 2.23 & 0.02 & 0.76 \\
\hline Portugal & 383.25 & 123.02 & 226.17 & 24.76 & 5.15 & 0.00 & 3.67 \\
\hline Romania & 238.63 & 167.69 & 63.23 & 5.09 & 1.61 & 0.00 & 1.01 \\
\hline Slovakia & 303.47 & 113.80 & 150.30 & 35.22 & 2.07 & 0.00 & 2.08 \\
\hline Slovenia & 230.67 & 112.98 & 62.03 & 45.12 & 5.32 & 0.04 & 5.16 \\
\hline Spain & 208.06 & 126.89 & 47.23 & 27.57 & 3.83 & 0.00 & 2.53 \\
\hline Sweden & 154.27 & 77.09 & 22.05 & 37.65 & 13.52 & 0.00 & 3.96 \\
\hline UK & $\mathbf{9 7 . 5 2}$ & 56.66 & 10.01 & 25.31 & 2.57 & 0.00 & 2.03 \\
\hline $\mathbf{E U}$ & 219.50 & 111.09 & 100.05 & 25.63 & 3.81 & 0.27 & 14.66 \\
\hline
\end{tabular}

${ }^{1}$ Research and development $/{ }^{2}$ Citizenship, freedom, security and justice $/{ }^{3}$ Actions and programmes outside the EU $/{ }^{4} \mathrm{Administration}$

Source: Author; Data: [11].

The hypothesis of a negative correlation between GDP per capita and budget spending per capita has not been confirmed. The correlation coefficient is even positive (0.616). One of the possible causes is a high administrative expenditure in rich countries (Luxembourg and Belgium) due to the headquarters of many European Institutions. By excluding these countries (Luxembourg and Belgium) from the analysis, a negative correlation appears, but it is still not significant (-0.354).

On closer analysis we can see that the only item that confirms the assumption is the regional policy, which is targeting redistribution:

- Agriculture (-0.099).

- Regional policy (-0.503).

- Research and development (0.741).

- Citizenship, freedom, security and justice (0.176).

- Actions and programmes outside the EU (-0.180).

- Administration (0.688).

- Total (0.606). 


\subsection{EU Policy of Stabilization}

Following a macroeconomic stabilization policy means allocating budget resources to the EU Member States with a high macroeconomic multiplier. This allocation of funds enables better control of macroeconomic output using fewer budget resources.

Table 3. Macroeconomic Multiplier in EU Member States (2007 to 2017)

\begin{tabular}{|l|r|r|}
\hline \multicolumn{1}{|c|}{ Country } & $\begin{array}{c}\text { Marginal Propensity to } \\
\text { Consume }\end{array}$ & $\begin{array}{c}\text { Macroeconomic } \\
\text { Multiplier }\end{array}$ \\
\hline Austria & 0.492 & 1.968 \\
\hline Belgium & 0.535 & 2.153 \\
\hline Bulgaria & 0.381 & 1.616 \\
\hline Croatia & 0.418 & 1.719 \\
\hline Cyprus & 1.926 & N/A \\
\hline Czechia & 0.521 & 2.087 \\
\hline Denmark & 0.429 & 1.751 \\
\hline Estonia & 0.389 & 1.636 \\
\hline Finland & 1.091 & $\mathrm{~N} / \mathrm{A}$ \\
\hline France & 0.502 & 2.006 \\
\hline Germany & 0.410 & 1.694 \\
\hline Greece & 0.487 & 1.950 \\
\hline Hungary & 0.283 & 1.395 \\
\hline Ireland & 0.075 & 1.081 \\
\hline Italy & 0.902 & 10.242 \\
\hline Latvia & 0.704 & 3.382 \\
\hline Lithuania & 0.655 & 2.897 \\
\hline Luxembourg & 0.214 & 1.272 \\
\hline Malta & 0.192 & 1.238 \\
\hline Netherlands & 0.270 & 1.370 \\
\hline Poland & 0.547 & 2.209 \\
\hline Portugal & 0.647 & 2.835 \\
\hline Romania & 0.538 & 2.165 \\
\hline Slovakia & 0.517 & 2.071 \\
\hline Slovenia & 0.640 & 2.778 \\
\hline Spain & 0.668 & 3.013 \\
\hline Sweden & 0.417 & 1.716 \\
\hline United Kingdom & 0.703 & 3.365 \\
\hline European Union & $\mathbf{0 . 4 9 0}$ & $\mathbf{1 . 9 6 1}$ \\
\hline
\end{tabular}

Source: [12-13].

Focusing on stabilization brings a strong positive correlation between the macroeconomic multiplier and EU budget expenditure. This would mean that the highest spending goes to countries with the greatest impact. 
Table 4. Structure of the EU Budget per Capita by EU Member States (EUR per Capita in 2017).

\begin{tabular}{|c|c|c|c|c|c|c|c|}
\hline Country & Total & Agriculture & $\begin{array}{c}\text { Regional } \\
\text { policy }\end{array}$ & $R \& D^{1}$ & Citizenship $^{2}$ & $\begin{array}{l}\text { Outside } \\
\text { the } \mathrm{EU}^{3} \\
\end{array}$ & $\operatorname{Admin}^{4}$ \\
\hline Austria & 203.23 & 140.70 & 9.91 & 42.16 & 7.51 & 0.00 & 2.94 \\
\hline Belgium & 653.54 & 46.86 & 27.23 & 128.28 & 22.72 & 0.00 & 428.45 \\
\hline Bulgaria & 263.21 & 140.89 & 87.11 & 25.90 & 7.76 & 0.01 & 1.54 \\
\hline Croatia & 156.94 & 74.11 & 64.47 & 10.25 & 2.76 & 3.23 & 2.12 \\
\hline Cyprus & 243.98 & 87.72 & 75.25 & 56.52 & 9.69 & 0.00 & 7.04 \\
\hline Czechia & 369.58 & 107.03 & 245.08 & 14.46 & 1.50 & 0.00 & 1.51 \\
\hline Denmark & 257.76 & 183.05 & 13.71 & 47.77 & 2.77 & 0.00 & 10.45 \\
\hline Estonia & 493.26 & 179.11 & 214.94 & 45.92 & 46.75 & 0.00 & 6.54 \\
\hline Finland & 274.25 & 159.58 & 47.07 & 55.44 & 5.63 & 0.00 & 6.52 \\
\hline France & 203.34 & 137.79 & 18.48 & 39.04 & 2.58 & 0.00 & 5.41 \\
\hline Germany & 134.57 & 74.75 & 25.39 & 29.24 & 2.00 & 0.00 & 2.81 \\
\hline Greece & 472.47 & 262.47 & 143.21 & 29.31 & 34.90 & 0.00 & 2.56 \\
\hline Hungary & 410.85 & 153.91 & 217.19 & 34.48 & 3.65 & 0.00 & 1.62 \\
\hline Ireland & 392.81 & 325.85 & 10.99 & 39.19 & 5.61 & 0.00 & 11.18 \\
\hline Italy & & 81.15 & 26.84 & 24.08 & 5.29 & 0.00 & \begin{tabular}{|l|}
4.57 \\
\end{tabular} \\
\hline Latvia & 370.93 & 198.53 & 147.19 & 13.75 & 7.28 & 0.00 & 4.18 \\
\hline Lithuania & & 244.78 & 234.64 & 45.41 & 10.59 & 0.00 & 3.63 \\
\hline Luxembourg & $3,245.55$ & 67.50 & 84.43 & 408.01 & 60.50 & 0.00 & $2,625.12$ \\
\hline Malta & 468.88 & 32.26 & 239.25 & 30.56 & 151.18 & 0.00 & 15.63 \\
\hline Netherlands & 143.02 & 53.34 & 11.36 & 55.71 & 15.76 & 0.00 & 6.86 \\
\hline Poland & 313.67 & 107.29 & 197.72 & 5.66 & 2.23 & 0.02 & 0.76 \\
\hline Portugal & 383.25 & 123.02 & 226.17 & 24.76 & 5.15 & 0.00 & 3.67 \\
\hline Romania & 238.63 & 167.69 & 63.23 & 5.09 & 1.61 & 0.00 & 1.01 \\
\hline Slovakia & 303.47 & 113.80 & 150.30 & 35.22 & 2.07 & 0.00 & 2.08 \\
\hline Slovenia & 230.67 & 112.98 & 62.03 & 45.12 & 5.32 & 0.04 & 5.16 \\
\hline Spain & 208.06 & 126.89 & 47.23 & 27.57 & 3.83 & 0.00 & 2.53 \\
\hline Sweden & 154.27 & 77.09 & 22.05 & 37.65 & 13.52 & 0.00 & 3.96 \\
\hline UK & $\mathbf{9 7 . 5 2}$ & 56.66 & 10.01 & 25.31 & 2.57 & 0.00 & 2.03 \\
\hline $\mathbf{E U}$ & 219.50 & 111.09 & 100.05 & 25.63 & 3.81 & 0.27 & 14.66 \\
\hline
\end{tabular}

${ }^{1}$ Research and development $/{ }^{2}$ Citizenship, freedom, security and justice $/{ }^{3}$ Actions and programmes outside the EU $/{ }^{4} \mathrm{Administration}$

Source: Author; Data: [11].

Nor has the second hypothesis assuming the implementation of an effective EU stabilization policy been confirmed (-0.172). In this case, most funds would have to be invested in countries with the highest macroeconomic multiplier (such as Italy), where public spending will be reflected in GDP ten times.

Similar results as for the overall budget also apply to each of its components, as can be seen in the overview of partial correlation coefficients:

- Agriculture (-0.117).

- Regional policy (-0.128).

- Research and development (-0.160).

- Citizenship, freedom, security and justice (-0.202).

- Actions and programmes outside the EU (-0.078).

- Administration (-0.131).

- Total (-0.172). 


\section{Conclusions}

The analysis has shown that the overall EU budget does not target redistribution, mainly because of the reimbursement of the costs associated with the seat of major authorities in Belgium and Luxembourg. The regional policy sub-item is redistributive. This implies two proposals, either to relocate some European institutions to poorer regions or to strengthen the importance of the regional policy.

Furthermore, the analysis showed that neither the overall EU budget nor its components are targeting effective stabilization. This would be achieved if expenditure were made in countries with a high marginal consumption rate and therefore with a high macroeconomic multiplier that would ensure a significant impact of the funds spent. The proposal is, therefore, to change targeted budgetary expenditure to such countries.

\section{References}

1. P. Samuelson, W. Nordhaus, Economics. $19^{\text {th }}$ ed. New Delhi: Tata McGraw Hill (2010)

2. J. Stiglitz, Economics of the Public Sector. $3^{\text {rd }}$ ed. New York: W. W. Norton and Company (2000)

3. S.K. Singh, D. Tripati Rao, Is monetary policy symmetrical in its effect on sectoral output? Economics, Management, and Financial Markets, 13(1), 11-31 (2018)

4. P. Garcia-Duran, L.J. Eliasson, Squaring the circle: Assessing whether the European union's pursuit of bilateral trade agreements is compatible with promoting multilateralism. Journal of Self-Governance and Management Economics, 6(1), 7-32 (2018)

5. R. Boadway, M. Keen, Efficiency and the optimal direction of federal-state transfers. International Tax and Public Finance, 3(137), 137-155 (1996)

6. A. Lindbeck, J. Weibull, Balanced-budget redistribution as the outcome of political competition. Public Choice, 52(3), 273-297 (1987)

7. D. Wildasin, Income redistribution in a common labor market. The American Economic Review, 81(4), 757-774 (1991)

8. D. Wildasin, Income redistribution and migration. The Canadian Journal of Economics, 27(3), 637-656 (1994)

9. A. Sacchi, S. Salotti, The impact of national fiscal rules on the stabilisation function of fiscal policy. European Journal of Political Economy, 37(C), 1-20, (2015)

10. Eurostat [online], Available at: https://ec.europa.eu/eurostat (2019)

11. European Parliament [online], Available at: https://www.europarl.europa.eu/portal/en (2019)

12. P. Rousek, M. Vochozka, M. Psárska, Analysis of the consumption on the goods and services market in the cybernetic model of the 15 older EU member states. AD ALTA: Journal of Interdisciplinary Research, 9(1), 252-254 (2019)

13. P. Rousek, Analysis of consumption on the goods and services market in the cybernetic model of selected country. SHS Web of Conferences: Innovative Economic Symposium 2018 - Milestones and Trends of World Economy (2019) 